UDC 94(477.83/.86):061.2 «ХIX» Крушельницький

DOI: 10.24919/2519-058x.10.159173

\title{
Ivan ZULYAK
}

Ph D hab. (History), Professor of the Department of History of Ukraine, Archeology and special branches of historical science, Ternopil Volodymyr Hnatiuk National Pedagogical University, M. Kryvonos, 2, Ternopil, Ukraine, postal code 46027 (ivanzuljak@gmail.com)

ORCID: https://orcid.org/0000-0003-3758-2019

ResearcherID: I-7574-2018 (http://www.researcherid.com/rid/I-7574-2018)

\begin{abstract}
Andriy KLISH
PhD (History), Associate Professor of the Department of History of Ukraine, Archeology and special branches of historical science, Ternopil Volodymyr Hnatiuk National Pedagogical University, M. Kryvonos, 2, Ternopil, Ukraine, postal code 46027 (klish_andriy@ukr.net)
\end{abstract}

ORCID: https://orcid.org/0000-0001-6074-6064

ResearcherID: I-7439-2018 (http://www.researcherid.com/rid/I-7439-2018)

Іван ЗУЛЯк

доктор історичних наук, професор кафедри історії України, археології та спеціальних галузей історичної науки Тернопільського національного педагогічного університету імені Володимира Гнатюка, вул. М. Кривоноса, 2, Тернопіль, Україна, 46027 (ivanzuljak@gmail.com)

\section{Андрій КЛІШ}

кандидат історичних наук, дочент кафедри історї Украӥни, археології та спеціальних галузей історичної науки Тернопільського національного педагогічного університету імені Володимира Гнатюка, вул. М. Кривоноса, 2, Тернопіль, Україна, 46027 (klish_andriy@ukr.net)

Бібліографічний опис статті: Zulyak, I. \& Klish, A. (2019). Anton Krushelnytskyi's participation in the activity of Ukrainian civil instutitions in Eastern Halychyna (the first third of the XXth century). Skhidnoievropeiskyi Istorychnyi Visnyk [East European Historical Bulletin], 10, 74-84. doi: 10.24919/2519-058x.10.159173

\section{ANTON KRUSHELNYTSKYI'S PARTICIPATION IN THE ACTIVITY OF UKRAINIAN CIVIL INSTUTITIONS IN EASTERN HALYCHYNA (THE FIRST THIRD OF THE XXth CENTURY)}

Summury. The purpose of the reseach: to reveal the participation of Anton Krushelnytskyi in the activities of Ukrainian public institutions in Eastern Halychyna during the analyzed period. The research methodology is based on the principles of historicism, a systematic approach, a scientific approach, a verifying approach, the author's objectivity, a moderate narrative constructivism, as well as the use of general scientific (analysis, synthesis, generalization) and special-historical (historical-genetic, historical-typological, historical-system) methods. One of the leading methods used by the authors was a biographical method that allowed to assess and determine the participation of A. Krush- 
elnytskyi in the activities of the Ukrainian public institutions in Eastern Halychyna, during the first third of the XXth century. The scientific novelty is the following: for the first time in Ukrainian historiography, on the basis of the analysis of the previously unknown archival documents and materials, it has been determined that A. Krushelnytskyi was directly involved in both Ukrainian economic and cultural-educational societies, in particular as an active member of the "Prosvita»in the towns of Horodenka and Kolomyia, as the head of the society's affiliate in the town of Rohatyn in the establishment of the readers-halls and libraries in the rural areas. Conclusions. The participation of A. Krushelnytskyi in the activities of Ukrainian public institutions in Eastern Halychyna during the analyzed period was a peculiar reflection of not only his outlook, but also an active living and civil position. A. Krushelnytskyi was an active member of «Prosvita» branch in Kolomyia, Horodenka, the head of the branch office of the company in Rohatyn, facilitated the establishment of reading rooms and libraries in the rural areas, and popularized Ukrainian academic works, published by the Main Department of the Institution. He gained authority among the literary and educational circles of Eastern Halychyna, societies and institutions.

Key words: Eastern Halychyna, Anton Krushelnytskyi, Prosvita, branch, Ukrainian public institutions.

\title{
УЧАСТЬ АНТОНА КРУШЕЛЬНИЦЬКОГО У ДІЯЛЬНОСТІ УКРАЇНСЬКИХ ГРОМАДСЬКИХ ІНСТИТУЦІЙ В СХІДНІЙ ГАЛИЧИНІ (ПЕРША ТРЕТИНА ХХ ст.)
}

\begin{abstract}
Анотація. Мета дослідження - розкрити участь Антона Крушельницького у діяльності украйнських громадських інституиій в Східній Галичині окресленого періоду. Методологія дослідження базується на принципах історизму, системності, науковості, верифікації, авторської об'єктивності, поміркованого наративного конструктивізму, а також на використанні загальнонаукових (аналіз, синтез, узагальнення) та спеціально-історичних (історико-генетичний, історико-типологічний, історико-системний) методів. Одним із провідних методів, яким послуговувалися автори, став біографічний, що дав змогу оцінити й визначити участь А. Крушельницького у діяльності украйнських громадських інституцій в Східній Галичині периої третини XX сm. Наукова новизна полягає у тому, що вперше в украӥнській історіографії, на основі аналізу невідомих раніше архівних документів і матеріалів, з'ясовано безпосередню участь А. Крушельницького як в украӥнських господарсько-економічних, так і культурно-просвітницьких товариствах, зокрема, як активного члена «Просвіти» у Городенџі й Коломиї, голови філії товариства у Рогатині у заснуванні читалень і бібліотек у сільських місиевостях. Висновки. Участь А. Крушельнищького у діяльності украӥнських громадських інститучій в Східній Галичині окресленого періоду була своєрідним відображенням не лише його світогляду, але й активної життєвої і громадянської позииії. А. Крушельнищький був активним діячем філії «Просвіти» у Коломиї, Городенці, головою філії товариства у Рогатині, сприяв заснуванню читалень і бібліотек у сільських місиевостях, популяризував твори, видані Головним виділом інституції. Користувався авторитетом серед українських наукових, літературних й освітніх кіл Східної Галичини, товариств та інституцій.
\end{abstract}

Ключові слова: Східна Галичина, Антін Крушельницький, «Просвіта», філія, украӥнські громадські інституції.

Problem statement. Among the prominent figures of the national-cultural movement in Eastern Halychyna, during the first third of the XXth century. A. Krushelnytskyi is a leader in politics, a writer, a publicist, a literary critic, a journalist, a translator, an educator, an editor and a publisher. Due to certain circumstances, his participation in the activities of Ukrainian institutions in Eastern Halychyna of the analyzed period has not been studied for today, which is a scientific novelty of this scientific publication. Therefore, the investigated problem is extremely relevant and necessary for the contemporary understanding of participation of A. Krushelnytskyi's participation in the activities of Ukrainian institutions in the Eastern Halychyna of the analyzed period.

The analysis of sources and recent researches. In spite of certain achievements of the scientists in the study of the above mentioned issues, there are many important unresolved 
problems beyond the limits of the research. The main attention is paid to the study of the pedagogical views of A. Krushelnytskyi (Chahrak, 2001). Some references to the cultural and educational activities of A. Krushelnytskyi are mentioned in the monographic works devoted to «Prosvita» (Zuliak, 2005).

Among the scientific researches a certain place is occupied by the issues of A. Krushelnytskyi's relationship with «Prosvita» (Zuliak, 2012; Topilskyi, 2016). Consequently, for a considerable period of the study of the above mentioned research theme there has been accumulated a certain amount of popular science literature, which in one way or another is tangent to the various aspects of the problem under investigation.

The main amount of the archival materials and documents, without which it is impossible to investigate the problem scientifically, to conduct a reasonable discussion and to make grounded conclusions, is concentrated in the Central State Historical Archives of Ukraine in Lviv (hereinafter referred to as the Central Intelligence Agency of Ukraine). In addition, the materials related to the participation of A. Krushelnytskyi in the activities of Ukrainian institutions in Eastern Halychyna of the analyzed period are used (Krushelnytskyi, 1909), «Letters from Prosvita» (Z zhyttia, 1913), «National Prosvita» (Zahalnyi Zbir, 1926; Zvit z diialnosti, 1926).

The publication's purpose. To reveal the participation of Anton Krushelnytskyi in the activities of Ukrainian public institutions in Eastern Halychyna during the analyzed period.

Statement of the basic material. A. Krushelnytskyi took an active part both in Ukrainian economic and cultural-educational societies. In particular, since September 2, 1909, he was a member of the «Pokutskiy union of crediting farm in Kolomyia» (the membership card number 664 - the note of the authors) and received $5 \%$ of an annual profit from his activities (Central State Historical Archive of Ukraine, Lviv, f. 361, d. 1, c. 144, p. 2a). On February 11, 1911, A. Krushelnytskyi, as a teacher of the gymnasium in Berezhany, was a member of the «Publishing Union of the Ukrainian Teachers in Kolomyia», having made two contributions of 40 krones (hereinafter - kr.) (CSHAUL, f. 361, d. 1 , c. 144, p. 10).

During 1909 - 1921 he earned a profit of $40 \mathrm{kr}$. (CSHAUL, f. 361, d. 1, c. 144, p. 11). From May 8, 1911, belonged to the «Mutual Credit Association» Hope in Berezhany», having received $20 \mathrm{kr}$. for the year 1911 profit (CSHAUL, f. 361, d. 1, c. 144, p. 14). In addition, since April 8, 1913, A. Krushelnytskyi was a member of the county credit union in Horodenka, a membership card number 764 (CSHAUL, f. 361, d. 1, c. 144, p. 19a). During 1913 he received the profit of $220 \mathrm{kr}$. (CSHAUL, c. 361, d. 1, c. 144, p. 21). On September 4,1917 , he resumes the membership in this company. From July 26, 1913 he is a member of the People's House in Horodenka with a share of $20 \mathrm{kr}$. and an introductory contribution 2 kr. (CSHAUL, f. 361, d. 1, c. 144, pp. 27, 32a). Although it is mentioned in the statute that the sum must not be less than 50 kr. (CSHAUL, f. 361, d. 1, c. 144, p. 28a).

Since October 1916 A. Krushelnytskyi was also a member of the «Trade Union» in Horodenka. However, due to the military actions, the union ceased its activities temporarily (CSHAUL, f. 361, d. 1, c. 145, pp. 41-44a). Since December 25, 1920, A. Krushelnytskyi was a member of the Union of Ukrainian Writers and Journalists (hereinafter - the UUWJ) (CSHAUL, f. 361, d. 1, c. 144, p. 48). Since December 27, 1927, he was a member of the Union of Ukrainian private clerks of Halychyna (hereinafter referred to as the UUPCH) (CSHAUL, f. 361, d. 1, c. 144, p. 49).

Despite the fact that he was a member of many economic institutions, as the mayor, he organized an election to a temporal public council in Horodenka on May 26-27, 1916 
(CSHAUL, f 361, d. 1, c. 145, p. 61), he supported the decision of the urban agrarian commission to appeal to the elders about the return of the horses used for the military purposes (CSHAUL, f. 361, d. 1, c. 146, pp. 57-57a). Nevertheless, his participation in the «Prosvita» activity was even more significant, although he actively collaborated with other Ukrainian institutions.

However, back in 1905 - 1906, A. Krushelnytskyi and other Ukrainian intellectuals, being in Stanislav, conducted free public lectures at the department of the pedagogical society (CSHAUL, f. 361, d. 1, c. 31, p. 1). Twenty-two lectures were conducted on various subjects (CSHAUL, f. 361, d. 1, c. 31, p. 1-3), of which A. Krushelnytskyi, as a member of the section of general scientific knowledge, conducted lectures on the following topics «Literary Sylvetka of the Novelist M. Kotsiubynskyi», «Khmelnytschyna», «Geography of Ukraine», «History of Ukraine from the Ancient times of the IXth century to the Formation of Kyiv principality», «On beauty», «From our New Lyrics»and the others (CSHAUL, f. 361, d. 1, c. 31 , p. 1-3).

According to the plan for conducting public lectures, it was planned to read twenty five lectures, but three did not take place. The reasons for it are unknown. The programme included the coverage of the following subjects, such as: History of Ukraine, Literature, Art, Law, Medicine and Nature Studies. The specialists who conducted the lectures were mostly the teachers of the gymnasium - 18 lecturers, by the teachers of the industrial schools -2 lecturers, by the doctors 1 person, by the lawyers -1 person (CSHAUL, f. 361, d. 1, c. 31, p. 3a) .

In 1906 - 1907, the Committee of the «Russian Dialogue» was charged with the public lectures with the payment of 10 sotykiv from the listener. A. Krushelnytskyi conducted lectures on the following topics: «Significance of Popular Statements», and M. Posatskyi «Philology as a Feeling and Science». The attendance at the lectures was 85 people, including 28 men, 33 women, and 24 students. The profit was $8.3 \mathrm{kr}$. The total profits from all lectures amounted to 27.96 kr. (CSHAUL, f. 361, d. 1, c. 31, p. 4, p. 6). A. Krushelnytskyi, in a certain way, cooperated with the Ukrainian reciter «Entertainment», who in 1907 asked him to provide the works for printing (CSHAUL, f. 361, d. 1, c. 153, p. 2).

Actually A. Krushelnytskyi started his career in «Prosvita» in 1908, being an active member of the affiliate of the society in Kolomyia, from 1913 - in Horodenka, and from 1925 as the head of the branch in Rohatyn. He was quite often elected as a delegate from the mentioned branches to the general meeting of the institute held in the city of Lviv (Zahalnyi Zbir, 1926, pp. 4-39; Zvit z diialnosti, 1926, pp. 233-247; Z zhyttia, 1913, p. 10-11). Being an active educator, he tried to implement the educational idea at the level of the the individual affiliates. The awareness of the goals and objectives of the educational activities of the intelligentsia was suggested by the author in the «Educational Lecture (from the jubilee bypass of affiliates branches «Prosvita»in Kolomyya on December 21, 1908)» (Krushelnytskyi, 1909).

A. Krushelnytskyi wrote about the cultural and educational work in «Prosvita» that «... when our activity is the one for Ukraine, for the Ukrainian people, for pushing ... in the educational, economic, political field, in a word the field of culture, then even our activity deserves recognition, even then it is good and ethical, then we still pay our duty for our people, and through our people for humanity» (Krushelnytskyi, 1909, p. 11).

In December 1913, at the general meeting of Prosvita branch in Horodenka, A. Krushelnytskyi took the floor with a speech dedicated to the future anniversaries of T. Shevchenko's birth in 1914, in which he emphasized the importance and significance of his ideas in the cathedral unification of Ukrainian lands. In particular, he emphasized: «... we spread and 
deepen the ideas of Shevchenko in advance, become a cultural people ...» (Krushelnytskyi, 1909, p. 10-11).

By the way, A. Krushelnytsky offered to name after T. Shevchenko all Ukrainian societies and structures created in the jubilee year 1914. This fact indicated the following: he realized the importance of T. Shevchenko works in Ukrainian culture. However, due to the circumstances connected with the beginning of World War I, the suggestion of A. Krushelnytskyi was never implemented.

Heading «Prosvita» branch in Rohatyn, A. Krushelnytsky promoted its activities quickly and brought in «Prosvita» branch to the leading centers of the institutions in Eastern Halychyna. In a relatively short time, the branch consisted of 49 active reading rooms. The higher education courses were organized by the branch activities together with the «Teachers' Community». The main purpose of the courses was the following idea «... higher education courses should not accumulate much knowledge in the heads of their students, but they should teach them the planned organization of the educational process and the methods of educational work so that they could guide the educational community with the help of self-education in order to obtain knowledge and better life conditions» (Zuliak, 2005, p. 758).

Being the Head of Prosvita branch in Rohatynshchyna, A. Krushelnytsky worked closely with the «Silskoho Hospodarya» branch (CSHAUL, f. 361, d. 1, c. 152, p. 53). He renovated the reading rooms of Prosvita branch in Rohatynshchyna actively. The meeting of the reading center section proved this renovation activity, dating back to December 30, 1922. According to the meeting, the area for the institution premises was bought. As it turned out, the bought area was small in size, but was determined by high price, $600 \$$. In addition to the search for Prosvita branch premises area, A. Krushelnytskyi began building Narodnyi Dim (People's House) in Rohatyn. On this occasion, he suggested to gather the meeting of Rohatyn inhabitants and the outskirt inhabitants in order to organize a committee concerning the building of Narodnyi Dim (People's House). At the meeting of Prosvita branch in June 16, 1926, the branch members composition and the branch functions were defined and approved (CSHAUL, f. 361, d. 1, c. 151, p. 1-1a). An important place in the work of the head of the branch was raising the money for the construction of T. Shevchenko monument in Rohatyn, a concert in Berezhany in honor of Kobzar (CSHAUL, f. 361, d. 1, c. 152, p. 52; CSHAUL, f. 361 , d. 1, c. 159 , p. 19).

The manual, issued by the main branches of «Prosvita» and «Native School», contained a practical organization of the youth work, the research of Ukrainian studies, physical education, cultural and artistic work: feasts, memorials, holidays, cooperation between the villages. An important place in the activity of the Main Department of Prosvita branch was assigned to the establishment of the so-called reading libraries, which in the long run should be the basis for the organization of national universities of orphanage type in order to develop professional education (Halushchynskyi, 1926, pp. 5-6, Halushchynskyi, 1927, p. 18).

A. Krushelnytsky, while analyzing the activity of Prosvita branch in 1924, wrote the following: «It is important to connect our whole educational activity into one whole, large, harmonious activity, to involve all our organizations into one joint affiliated effort, to give the firm material and moral foundation...» (CSHAUL, f. 361, d. 1, c. 152, p. 1a).

A. Krushelnytsky pursued the activity of establishing the reading rooms and libraries in villages actively. The vivid example of such activity was his delivered speech at the meeting on August 16, 1925 in Burshtyn. He emphasized that Prosvita branch situation was rather complicated, therefore, he suggesteded to organize an office at the presence of each branch 
department that would control the development of cultural and educational life and support reading rooms financially and morally. A. Krushelnytsky founded Ivan Franko district library, which had 415 volumes of literary works, and the so-called «travelling» library for readers consisted of 121 books. Three sections were organized at the branch: organizational, teaching and humanistic (Zvit z diialnosti, 1926, p. 244). There were 12 A. Krushelnytskyi's own works in «Prosvita» branch in Rohatyn with the total sum -58.9 zloty (zl). The sum of the other authors works was 466,9 zl. (CSHAUL, f. 361, d. 1, c. 152, pp. 24-28).

Taking into account the complicated situation with the organization of the library business, the Main Branch decided to create the sets of the so-called «travelling» libraries since autumn, 1924 (Halushchynskyi, 1924, p. 103). A. Krushelnytsky mentioned that the creation of the «travelling» libraries required significant efforts, «... hardly managed to make 30 sets, each set included 50 books; and in these 30 sets I had to duplicate some books» (CSHAUL, f. 361, d. 1, c. 152, p. 12). Although, he estimated «Prosvita» publishing work positively.

There was the list of the cheapest editions of various content available to every Ukrainian provided by the «Folk Illustrated Calendar of Prosvita Society for 1925 year» (Vydannia, 1924, pp. 101-104). At the general meeting of Prosvita branch in 1925, A. Krushelnytskyi, as a delegate from Rohatyn, noticed that the publication of the society should be available to every Ukrainian. Emphasizing the importance of Prosvita publishing activity, he noted that because of the weakness of connection (the main department - the branch - the reading room), the society does not contribute to making its publications more available/ accessible to each community. In his opinion, it was necessary to implement changes to the branch regulations, so that the readers became not only the members of Prosvita, but also paid a low membership fee (Zahalnyi Zbir, 1926, p. 13).

M. Halushchinsky in the article «Prosvita Publishing Activity» pointed out that if the affiliates would pay monthly for the received literature from 200 to 500 thousand zl. in cash, in this case the Main Department would conduct the publishing activities for the educational work benefit (Halushchynskyi, 1923, p. 2). The important place in publishing activities of the company was given to the publication of the popular literature, so the Main Department encouraged the affiliates and the reading rooms to buy and subscribe to their libraries. On June 16, 1929 in Lviv, on the celebration of «Prostiva», dedicated to the memory of Ivan Franko, A. Krushelnytskyi took the floor with the speech «Revolutsionerovy and Kamenyarevy» (Krushelnytskyi, 1929, pp. 85-96). On September 22, 1926, he ordered the society editions for the sum of $1643.1 \mathrm{\kappa p}$ (calculated by the authors) in the Office of the Main Department of Prosvita (CSHAUL, f. 361, d. 1, c. 151, pp. 29-31). Incidentally, NTSh in a letter sent to A. Krushelnytsky in April 21, 1908 reported on the material assistance to Ivan Franko, who «... provided for the family exclusively by literary earnings. For now and for the future there is no point to talk about them. His relatives and he himself are left without any means of life, without the need for a medical aid and appropriate care» (CSHAUL, f. 361, d. 1, c. 153, p. 3).

Prosvita branch in Berezhany on October 30,1927, held a week exhibition of books, a course for librarians, and therefore asked A. Krushelnytskyi not only to be a participant, but also planned to arrange an exhibition of his works. As an active educator, the head of the company's affiliate in Rohatyn, A. Krushelnytskyi was invited to an educational congress, dedicated to the 60th anniversary of Prosvita foundation. He was a delegate of the general institution meetings for numerous times (CSHAUL, f. 361, d. 1, c. 151, pp. 34, 35, 41).

However, the literary activity of A. Krushelnytskiy played an important role not only in «Prosvita» activity, but also in the cultural and educational life. Prosvita popularized and 
distributed his creative work, even after the death of the latter. In particular, in the «Catalogue of the Bookstore of Prosvita Society», he presented his works «Cutting out Forest Trees» and «Ivan Franko» (Katalog, 1939, pp. 4-35). Incidentally, the works of «Ivan Franko», «By Strong Wing Move» and «Reader Fifth for the Fifth Grade in a Unified School» were prohibited by Polish authorities (Magalias, 1937).

A certain part of «Prosvita» branches, although prohibited by the charter, tried to pursue political activities, so the Main Department of the company required to send the report of the general meeting of the branch in Rohatyn, informing A. Krushelnytskyi that «... blame is ridiculous, so comrades can be calm» (CSHAUL, f. 361, d. 1, c. 152, p. 20 p.). Nevertheless, on March 8, 1927, a meeting of the Main Department of «Prosvita» was held at which the issue of holding the general meeting of the branch in the Rohatyn was discussed. They stressed that the head of the branch A. Krushelnytskyi was not entitled to hold the general meeting, because from their several readers their representatives did not have the powers of the head of the society, respectively, did not take part in the voting because the hall for the meeting was too small, that's why, not all delegates and guests were able to get to their venue. The head office of Prosvita considered the branch of the Society in Rohatyn to be the Secretariat of the Socialist Party (CSHAUL, f. 361, d. 1, c. 152, p. 36).

An important place in A. Krushelnitsyi's educational life was his direct participation in the functioning of the SUPIZh, which took place in Vienna on October 15, 1920. Actually, he was invited to a joint meeting of the Board on the organization of lectures and the conduct of literary evenings (CSHAUL, f. 361, d. 1, c. 153, p. 22).

A. Krushelnytskyi was a member of SUPIZH in Vienna, as evidenced by the appeal of the institution's board regarding the payment of a monthly membership fee of $10 \mathrm{kr}$., Entrance fee $-10 \mathrm{kr}$., the production of a certificate $-20 \mathrm{kr}$. He has repeatedly attended the meeting of the SUPIZH Executive Council (CSHAUL, f. 361, d. 1, c. 153, pp. 23, 26).

In June 23, 1925, A. Krushelnytskyi was invited by the Ukrainian Pedagogical Society to the Congress of Directors of Gymnasium and Seminary in Lviv, which was planned to be held in July 2 of this year, and he had to make a presentation on the educational issues (CSHAUL, f. 361, d. 1, c. 153, pp. 29, 32). The Board of Teachers of Ukrainian Private Secondary Schools at the «Teachers' Community» invited him to a general meeting (CSHAUL, f. 311, d. 1, c. 9, p. 67). A. Krushelnytskyi participated in the work of the educational and teaching commission at «Prosvita» branch named after T. Shevchenko in Lviv (CSHAUL, f. 361 , d. 1, c. 151 , pp. 37,38 ).

In addition, he tried to create scholarships funds for the gifted Ukrainian youth in order to give them a material support. The scholarship project fund was suggested by A. Krushelnytskyi under the Ministry of National Education of the Ukrainian People's Republic. In his opinion, it was necessary to announce a competition for 25 scholarships for Philosophy and Law students, Medicine and Technology students for 2 thousand kr. monthly for one year from March 1, 1920 - until February 28, 1921, in the amount of 600 thousand kr. The terms of the competition were the following: the preliminary work or service in the Ukrainian army; the absence of any material support; the results of study in six months from subjects that have not less than 20 hours; a statement that after graduation the student will work in the civil service in the Ukrainian People's Republic for six years (CSHAUL, f. 361, d. 1, c. 146, p. 91).

The editorial office of the magazine «Novyi Chas» on the occasion of the 10th anniversary of I. Franko death planned to publish the information about him and those persons who 
were personally familiar with him monthly, in order «... to magnify the memory of our great Teacher, but to prolong the details about his life» (CSHAUL, f. 361, d. 1, c. 153, p. 35) hence, asked A. Krushelnytskyi to submit such information. As a matter of fact, the editorial staff appealed to him on this occasion, as it can be explained by the fact that he had personal and friendly relations with I. Franko, who acted not only as a critic of his works, but also as a mentor to a certain extent.

This information was stated in the articles written by S. Trofymuk «Antin KrushelnytskyiIvan Franko's correspondent» (Trofymuk, 1968, pp. 146-147), B. Romanenchuk «Literary Kolomyia» (Romanenchuk, 1988, pp. 197-226) and M. Zuliak «Antin Krushelnytskyi - popularizer of Ivan Franko's work» (Zuliak, 2013, pp. 117-120). By the way, in A. Krushelnytskyi's articles dedicated to Ivan Franko, the author tries to submit not only Kamenyar's childhood, but also to convey his feelings related to his childhood, his native village, elementary school, gymnasium, and the outlook formation. An important place is devoted to the social environment, which had influence on the formation of Ivan Yakovlevich as a person.

A. Krushelnytskyi cooperated with the Scientific society named after T. Shevchenko (hereinafter - NTSh) actively, has attended the general meeting of the institution for many times (CSHAUL, f. 361, d. 1, c. 158a, p. 1). In April 10, 1926, the NTSH, in person of the head K. Studynskyi, addressed to A. Krushelnytskyi in order to celebrate with dignity the same I. Franko's anniversary by publishing memoirs of his life, the manuscripts, and the others. For the above mentioned materials, a separate archive room of I. Franko at the institution's premises was forseen by the NTSh (CSHAUL, f. 361, d. 1, c. 153, p. 36). A. Krushelnytskyi cooperated with higher educational institutions. Thus, Kamyanets-Podilskyi State University, founded in 1918, appealed to him about the transfer of all his works for the library needs (CSHAUL, f. 361, d. 1, p. 158a, p. 5). By the way, A. Krushelnytskyi has repeatedly worked in the funds of this library. The main evidence of the above mentioned fact was the permission of the rector of the university, given to A. Krushelnytskyi in September 15, 1919, that he was allowed to work in the university library (CSHAUL, f. 361, d. 1, c. 144, p. 44).

A. Krushelnytskyi had an undeniable international authority, therefore the Ukrainian Academic Committee in Prague invited him to attend the Scientific Congress, which was to take place in October 3-6, 1926 (CSHAUL, f. 361, d. 1, c. 153, p 38). He was a renowned litterateur, a writer, a publicist, and a literary critic, therefore, the «Society of Ukrainian Writers and Journalists named after I. Franko» in Lviv invited A. Krushelnytskyi to commemorate the 40th anniversary of the literary work of O. Kobylyanska and A. Tchaikovskyi, the anniversary of the Academician V. Shchurat, K. Studinskyi (CSHAUL, f. 361, d. 1, c. 153, pp. 41-42, 52; CSHAUL, f. 361, d. 1, c. 158a, pp. 20, 21, 42). In connection with the festive concert, organized by «Prosvita» branch named after T. Shevchenko in Lviv, dedicated to the anniversary of I. Franko, A. Krushelnytskyi was invited to deliver a speech on the occasion of the consecration of the third stamp unit flag of the Ukrainian elder Plastuns (CSHAUL, f. 361 , d. 1, c. 151 , p. 33; CSHAUL, 361, d. 1, c. 158a, p. 24).

Having a powerful authority of a public figure and a teacher, the Ukrainian Academic Gymnasium in Lviv invited A. Krushelnytskyi to the concert devoted to the 68th anniversary of T. Shevchenko's death, and the State Gymnasium students of the city - to the concert, dedicated to Shevchenko, the opening of the Bursa named after St. John the Baptist in Drohobych, etc. (CSHAUL, f. 361, d. 1, c. 159, pp. 29, 30, 33).

He belonged to SURPRUHY, being invited to the meeting of the above mentioned institution in Lviv in May 7, 1928 (CSHAUL, f. 361, d. 1, c. 153, p. 43). According to the 
archival materials, in 1929 A. Krushelnytskyi belonged to the organizational committee of this society (CSHAUL, f. 361, d. 1, c. 153, p. 45). The National Museum in Lviv invited him in 1913 for the transfer of collections for public use (CSHAUL, f. 361, d. 1, c. 158a, p. 3). In 1932 he was invitated to the opening of the exhibition dedicated to I. Mazepa (CSHAUL, f. 311 , d. 1 , c. 9 , p. 9).

While in Vienna, A. Krushelnitskyi spent an active cultural life. He was often invited to such events as «Andriyivski Vechornytsi», organized by the societies «Sich» and «Supporters of Education», for watching the performance «Autumn Violins», «The Fourth Performance», a gala evening in the honor of M. Pavlyk. A group of «Sichovykh Striltsiv» he was invited to worship with a memorial service for the fallen in battles for Ukraine's independence, the 10th anniversary of USS foundation, the opera great masquerade «Koza-Dereza» etc. (CSHAUL, f. 361 , d. 1 , c. $158 \mathrm{a}$, pp. $8-10,11,12,15 \mathrm{a}, 17,40)$.

The end of the 20-ies of the XXth century in Eastern Halychyna was characterized by a rather difficult situation in which Ukrainian schools were found, which was directly connected not only with their forcible polonization, but also with the total elimination of the Polish authorities. However, A. Krushelnytskyi, as a well-known teacher, the director of the gymnasium, invited the «Teacher Community» to meet on the creation of a committee to protect Ukrainian school structures and discuss other current issues (CSHAUL, f. 361, d. 1, c. 153, p. 44, 48, 48).

A. Krushelnytskyi had the authority among the Ukrainian literary and educational circles of Eastern Halychyna, the societies and institutions. The main Prosvita branch, its branch in Berezhany, as well as local centers of the «Union of the Ukrainians», the «Teacher's Community», the circle of the «Ukrainian Pedagogical Society», the «Ukrainian Bursa», the «Protection of Children and Youth Care Society», The Blessed Virgin Mary sister-nuns, the «Berezhanskyi Boyan», the bourgeois reading room, the «Mutual Teaching Aid», the People's House (Narodnyi Dim), the «Nadiya» cooperative, the Union Cooperative, the «Silskyi Hospodar» and the others, welcomed him on the occasion of the 25th anniversary of literary work and the 50th birthday anniversary and significant achievements with the following words: «in the field of the national literature, enriched the nationwide cultural treasury, made You very dear and close to our Society, which has been guarding the Ukrainian culture for a dozen years» (CSHAUL, f. 361, d. 1, c. 159, p. 4-4a, 7-7a, 8).

The Ukrainian Academic Community in Prague, "Teacher's Community» branch in Przemysl, Prosvita branch in Rohatyn, Prosvita reading rooms in Psara, Knyahynychakh, Danylchi, Potok, the Ukrainian private seven grade school named after O. Storozhenka in Brest, the group of Ukrainian national youth high schools in the Czechoslovak Republic, the Ukrainian National-Democratic Association, the «Union of the Ukrainian Theater Teachers», the publishing house «Zhuravli», «Teachers' Community», Andriy and Anna Zhuki other persons and Institutions also welcomed the jubilee (CSHAUL, f. 361, d. 1, c. 159, pp. 12, 16, 18, 19-19a, 20, 28, 31, 35, 37-42, 75).

He had a significant impact on the working environment. This is evidenced by the letter of the Cultural and Educational Section of the «Workers' Theater» in Lviv, dated back to March 31, 1934, when the leadership of the section referred to him about the transfer of his books for the library's needs of the theater (CSHAUL, f. 361, d. 1, c. 153, p. 59).

Conclusions. The participation of A. Krushelnytskyi in the activities of Ukrainian public institutions in Eastern Halychyna during the analyzed period was a peculiar reflection of not only his outlook, but also an active living and civil position. A. Krushelnytskyi was an active member of «Prosvita» branch in Kolomyia, Horodenka, the head of the branch office of the 
company in Rohatyn, facilitated the establishment of reading rooms and libraries in the rural areas, and popularized Ukrainian academic works, published by the Main Department of the Institution. He gained authority among the literary and educational circles of Eastern Halychyna, societies and institutions.

The perspective of a further scientific research related to Anton Krushelnytskyi's personality is the analysis of his journalistic and epistolary heritage, which will deepen and broaden our knowledge of this remarkable personality greatly, his contribution to socio-political, economic, and educational life of Eastern Halychyna at the end of the XIXth - the first third of the XXth century.

Acknowledgments. The authors of the publication express the sincere gratitude to the director and the employees of the Central State Historical Archives of Ukraine in Lviv for the support and assistance in search of the archival material.

Funding. The authors received no financial support for the research, authorship, and/or publication of this article.

\section{BIBLIOGRAPHY}

Chahrak, N. (2001). Hromadsko-prosvitnytska diialnist A. Krushelnytskoho na Bukovyni (1912 - 1916) [Public-educational activity of A. Krushelnytsky in Bukovina (1912 - 1916)]. Naukovyi visnyk Chernivetskoho universytetu, 127: Pedahohika ta psykholohiia, 181-184 [in Ukrainian].

Halushchynskyi, M. (1923). Vydavnycha diialnist «Prosvity» [Publishing activity «Prosvita»]. Dilo, 17 lypnia, 2. [in Ukrainian].

Halushchynskyi, M. (1924) Mandrivni biblioteky Tovarystva «Prosvita» [Traveling Libraries of «Prosvita» Society]. Narodnia Prosvita, 7, 103. [in Ukrainian].

Halushchynskyi, M. (1926). Novymy shliakhamy. Peredruk $z$ «Lit.-Nauk. Visnyka», kn. 1, za 1926 r. [New ways. Reprint from «Lit.-Science Bulletin», book 1, 1926]. Lviv. 7 p. [in Ukrainian].

Halushchynskyi, M. (1927). Pozashkilna osvita (Narodyny, - Osvitni ustanovy, - Organizatsiini formy, - Meta.). Z 27 iliustratsiiamy [Out-of-school education (Families, - Educational institutions, Orgional forms, - Purpose). With 27 illustrations]. Lviv, 718, 45 p. [in Ukrainian].

Katalog knyharni tovarystva «Prosvita» (1939). [Educational lecture: From the jubilee bypass of the branches of «Prosvita» in Kolomyia, 21.12.1908]. Lviv 861, 4-35. [in Ukrainian].

Krushelnytskyi, A. (1909). Prosvitnii referat: Iz yuvileinoho obkhodu filii «Prosvity» v Kolomyi 21.12.1908 r. [Educational lecture: From the jubilee bypass of the branches of «Prosvita» in Kolomyia, 21.12.1908]. Kolomyia, 58 p. [in Ukrainian]

Krushelnytskyi, A. (1929). Revoliutsionerovy i Kameniarevy [A revolutionary and a bricklayer]. Novi shliakhy, 3, 85-96. [in Ukrainian].

Magalias, S. (1937). Spys skonfiskovanykh i zaboronenykh ukrainskykh knyzhok ta drukiv u Polshchi do 30. chervnia 1937 r. Poradnyk dlia bibliotek [A list of confiscated and forbidden Ukrainian books and prints in Poland until June 30, 1937. Advisor to libraries]. Lviv, 75 p. [in Ukrainian].

Romanenchuk, B. (1988). Literaturna Kolomyia [Literary Kolomyia]. Kolomyia y Kolomyishchyna. Zbirnyk spomyniv i stattei pro nedavnie mynule. Filadelfiia: Vydannia Komitetu Kolomyian, 197-226. [in Ukrainian].

Topilskiy, A. G. (2016). Rol «Prosvity» v formirovanii ukrainskogo natsionalnogo samosoznaniya v vostochnoy Galitsii (konets $60-\mathrm{kh}$ gg. XIX - nachalo XX v.) [The role of «Prosvita» in the formation of Ukrainian national self-consciousness in Eastern Galicia (at the end of 60-s XIX - the beginning of XX century)]. Vestnik Tambovskogo universiteta. Seriya: Gumanitarnye nauki. Tambov, 21, 7-8 (159-160), 118-122. doi: 10.20310/1810-0201-2016-21-7/8(159/160)-118-122 [in Russian].

Trofymuk, S. (1968). Antin Krushelnytskyi - korespondent Ivana Franka [Antin Krushelnytsky correspondent of Ivan Franko]. Zhovten, 9, 146-153 [in Ukrainian].

Tsentralnyi derzhavnyi istorychnyi arkhiv Ukrainy, m. Lviv [CSHAUL - Central State Historical Archive of Ukraine, Lviv]. [in Ukrainian]. 
Vydannia Tovarystva «Prosvita». Naideshevshi vydannia z polia vsikh tsaryn liudskoho znannia prystupnykh dlia kozhnoho ukraintsia (1924) [Publications of the Society «Prosvita». The cheapest publications from the field of all fields of human knowledge applicable to each Ukrainian]. Narodnii Iliustrovanyi Kaliendar Tovarystva «Prosvita» na zvychainyi rik 1925, Lviv, 101-104. [in Ukrainian].

Z zhyttia filii «Prosvity» (1913) [From the life of the branches of Prosvita]. Pysmo z «Prosvity», 4, 10-11. [in Ukrainian].

Zahalnyi Zbir Tovarystva «Prosvita» u Lvovi (1926) [The General Collection of the «Prosvita» Society in Lviv]. Narodnia Prosvita, 1-2, 4-39. [in Ukrainian].

Zuliak, I. S.(2005). Diialnist «Prosvity» u Zakhidnii Ukraini v mizhvoiennyi period (1919 - 1939) [Activities of «Prosvita» in Western Ukraine in the interwar period (1919 - 1939)]. Ternopil: «Volia», 946 p. [in Ukrainian].

Zuliak, M. (2012). Antin Krushelnytskyi i «Prosvita»[Antin Krushelnytsky and Prosvita] Problemy ta perspektyvy nauk $v$ umovakh hlobalizatsii: VIII Vseukrainska naukova konferentsiia (pp. 145-148). Ternopil. [in Ukrainian].

Zuliak, M. I. (2013). Antin Krushelnytskyi - populiaryzator tvorchosti Ivana Franka [Antin Krushelnytsky - popularizer of Ivan Franko's work]. Visimnadiatsiata Vseukrainska naukova konferentsiia molodykh istorykiv nauky, tekhniky i osvity ta spetsialistiv, prysviachena 150-richnomu yuvileiu V. I. Vernadskoho: Materialy konferentsii (pp. 117-120). Kyiv. [in Ukrainian].

Zvit z diialnosti tovarystva «Prosvita» za chas vid 25 hrudnia 1925 roku do 24 hrudnia 1926 roku. Diialnist poodynokykh filii (1926) [Report on the activities of the «Prosvita» Society for the period from December 25, 1925 to December 24, 1926. Activities of individual branches]. Narodnia Prosvita, 9-10, 233-247. [in Ukrainian].

The article was received on January 16, 2019. Article was recommended for publishing 4.03.2019. 